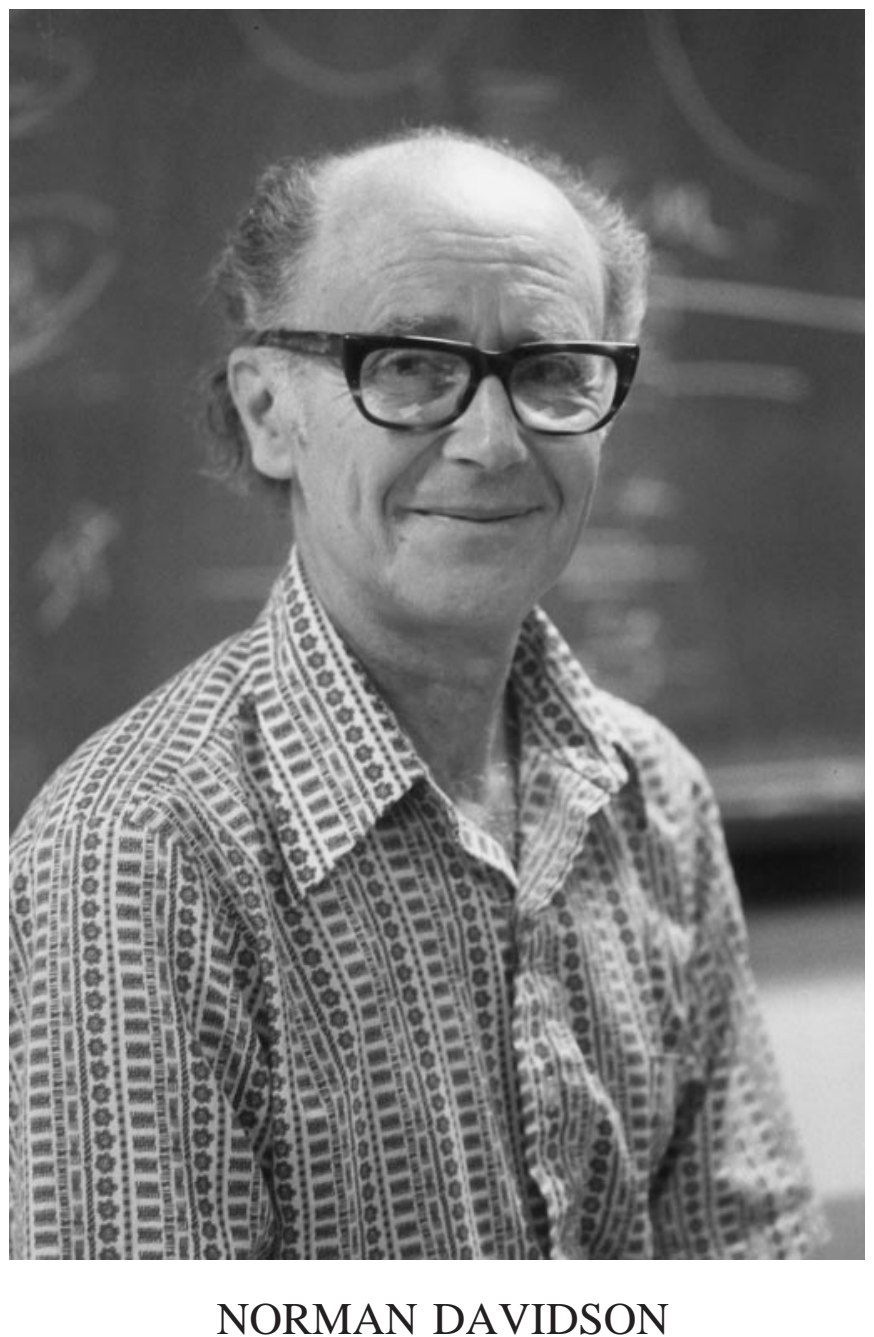




\title{
My Career in Molecular Biology
}

\author{
Norman Davidson \\ Division of Biology, California Institute of Technology, Pasadena, California 91125
}

Key Words DNA, denaturation, heteroduplexes, drosophila, electrophysiology, BDNF, actin genes

\section{In Memoriam}

Norman Davidson was born April 5, 1916, in Chicago, Illinois. He became a chemistry instructor at the California Institute of Technology in 1946 and remained on the faculty until his death February 14, 2002, in Pasadena, California.

Abstract Norman Davidson's training as a physical chemist led him to make key early contributions to the chemistry of DNA. He described the details of DNA denaturation and renaturation, concepts that still form the basis for understanding hybridization. He also applied the single-molecule resolution of the electron microscope to describing the chemistry of circular DNA, mapping specific genes, and characterizing heteroduplexes. The latter became a dominant tool for the study of nucleic acids and contributed to our knowledge of transcription, polyadenylation, and retroviral structure. The advent of cDNA cloning and restriction enzymes enabled Davidson to describe the diversity of Drosophila actin genes and to isolate the gene encoding cAMP phosphodiesterase. Davidson then turned his attention to neuroscience and participated in cDNA cloning, oocyte expression, and structure-function studies of nicotinic acetylcholine receptors, voltage-gated sodium channels, a GABA transporter, a G protein-gated potassium channel, and calcium channels. His interests also extended to synaptic plasticity, and he helped to define the role of neuronal nitric oxide synthase and of trkB receptors. His final experiments concerned the role of protein kinase A in long-term potentiation. (The abstract was written posthumously by a colleague.)

\section{CONTENTS}

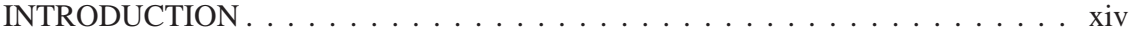
STUDIES OF DNA . . . . . . . . . . . . . . . . xiv

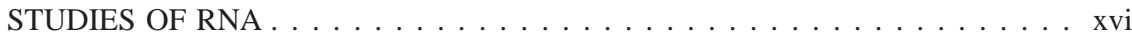

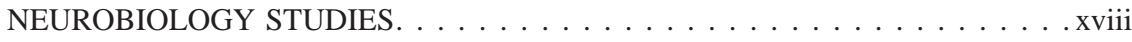




\section{INTRODUCTION}

It is pertinent to mention that I received my Ph.D. in inorganic chemistry from the University of Chicago in 1939. I worked on the chemical problem of purifying plutonium for the atomic bomb project from 1939 to 1945 . When I came to Caltech in 1946, I took up research in both physical chemistry and inorganic chemistry. The latter will be relevant later, but initially it provided small projects for undergraduate research involving the chemistry of various ligands with $\mathrm{Hg}^{++}$ions. I also did some research in which we pioneered the use of shock waves in studying very fast reactions as well as using flash lamps for studying fast reactions (1). This is completely unrelated to molecular biology, but it resulted in my being elected to membership in the National Academy of Sciences in 1960 . This kudo was very useful in my promotion at Caltech and my independence to shift fields from time to time.

\section{STUDIES OF DNA}

Some time around 1958 or 1959 , I was thinking about switching to biologyrelated research. There was a biophysicist (an electron microscopist actually) at MIT named Frances O. Schmitt. He had a very good ear to the ground because he came to Caltech and invited me to a Conference on Biophysics in Boulder, Colorado. At Caltech, Alex Rich, who was then a postdoctoral student with Linus Pauling, had given an informal evening talk or two on ion channels. At those meetings I learned that ion channels were selective for either sodium ions or for potassium ions. This fascinated me because I knew from my undergraduate analytical chemistry course how difficult this separation was.

Bernard Katz, who was one of the original investigators who had discovered the properties of ion channels in the squid axon, was at the meeting. I told him about my interest in doing something chemical about ion channels. He advised me to forget about it because the density of ion channels in the squid axon was only about 1 per $\mu \mathrm{m}^{2}$, and it would be impossible to isolate a sufficient quantity to do anything chemical. He was of course right because before recombinant DNA and cloning came along it was not possible to do anything other than electrophysiological studies. Our work on cloning a sodium channel is discussed below. In any case I decided, based in part on the advice of B. Katz, that of the several fields I had heard discussed at this meeting, the one most suitable for biochemical studies was DNA.

Incidentally, Leo Szilard, a physicist who had participated in the prewar and wartime work on the atomic bomb, had developed an interest in biology and was at the conference. He sat in the front row. He would listen to each one-hour speaker for about three minutes. If he thought the talk was boring, he would slowly walk out so that the speaker and everyone in the audience could see him. 
I was always hopeful from the title that the talk would be interesting, but Szilard was never wrong. Szilard died of cancer a year later; in retrospect, I wonder if he already knew this.

Our first studies in molecular biology, like those of many other authors, were of the denaturation of DNA. One of my first graduate students in this field was William F. Dove. He showed that denaturation could be studied at low ionic strengths by using stringent purification procedures for the electrolyte in which the DNA was dissolved. He observed that the melting temperature was a linear function of the log of the ionic strength. At low ionic strength, $\mathrm{Mg}^{++}$and $\mathrm{Co}^{2+}$ were bound, essentially stoichiometrically, by the DNA and raised the melting temperature (2). Dove has gone on to a brilliant career at the University of Wisconsin in the study of mouse models for several cancers.

Tetsuo Yamane, as a graduate student, studied the chemistry of the $\mathrm{Hg}^{++}$ion with various ligands. We knew that $\mathrm{Hg}^{++}$bound covalently to nitrogen atoms relatively strongly. As a postdoctoral student, Yamane showed that $\mathrm{Hg}^{++}$did bind strongly to DNA, probably with one $\mathrm{Hg}^{++}$per base pair, by observation of an increase in buoyant density of the DNA in a $\mathrm{Cs}_{2} \mathrm{SO}_{4}$ gradient (3).

I should explain that it was known from ultraviolet spectrophotometric studies that the absorption spectrum of DNA, which showed a peak at $2500 \AA$, increased when it was thermally denatured and rapidly cooled so that very little renaturation occurred. The reduced light absorption in the native state was attributed to interaction of the aromatic rings of the several bases in the Watson-Crick structure. The DNA complexed with $\mathrm{Hg}^{++}$showed the same increase in UV absorption as did thermally denatured DNA. Thus, the structure, although still double stranded, was disordered without base stacking.

In further work we showed that the subcomponent of copolymer of polydA: polydT in native crab DNA could be separated from the main component by preparative density gradient centrifugation in the presence of $\mathrm{Hg}^{++}$. Thus, $\mathrm{Hg}^{++}$ binding to AT base pairs is stronger than that binding to GC base pairs (4).

James C. Wang came to my laboratory as a postdoctoral student after a degree from the University of Missouri. He did some excellent work on the thermodynamics of the conversion of circular to linear bacteriophage lambda DNA by virtue of the complementary single-strand ends (5). He has gone on to a brilliant career at Harvard University in the study of DNA topoisomerases.

James Wetmur came to Caltech as a graduate student in about 1965. A.K. Kleinschmidt had come to spend a summer at Caltech, and Wetmur learned from him about his basic protein film method for spreading DNA on a membrane film that consisted of parlodion and the basic protein cytochrome. I was excited by this methodology because instead of studying the average properties of a polymer, one could see the shapes of individual molecules. For many years this electron microscopic approach was central to our research.

Wetmur and I wrote an article on the kinetics of renaturation of DNA (6). This article was very popular for half a decade or so because it enabled researchers to determine the sequence complexity and average length of a sample as well as whether the DNA contained repetitive sequences, which are in fact distributed throughout most eukaryotic genomes. 
Ronald W. Davis was admitted to Caltech in about 1965. He started off on a small uninteresting project that I had suggested. He conceived the idea of mapping the region where two phage lambda transducing phages differed by denaturation, renaturing a solution of the two, and then examining them by electron microscopy. When spreading DNA from aqueous solution, duplex DNA appeared as a linear region, but single strands were collapsed into what we called a bush. At any region in which the two sequences differed, one could see a bush. Thus, the sites for deletions or insertion of a reporter gene such as that coding for lacZ would appear as a bush. This work was published in 1968 (9).

At about the same time, Barbara Westmoreland, Warlaw Szybalski, and Hans Ris at the University of Wisconsin had conceived the same idea. Their work was published in Science (10). They introduced the use of formamide at a concentration of $40 \%-50 \%$ in the spreading solution. This is a moderate denaturing agent that causes dissociation of the weak hydrogen bonds formed between various bases in the single-strand region, which are then seen in the electron microscope as a less electron-dense smooth curve. The duplex regions are not affected.

Around 1971, Phillip Sharp came to my lab as a postdoctoral student. He was one of a small group who used electron microscopy to study the structures of the R-factors that are important for transferring antibiotic resistance between bacteria and F-prime factors (7). I should first state that an F-prime factor contains the basic $\mathrm{F}$ factor that contains the genetic information for transfer from one bacterium to another and for which we found a length of about $94.5 \mathrm{~kb}$. An F-prime factor contains additional genes, such as lacZ, that are useful to the bacterium. We noted that there were specific points on the F chromosome where these other genes integrated, and these were at one or the other end of an insertion sequence. We discovered that the insertion sequences, which were usually of length $1-4.5 \mathrm{~kb}$, contained a palindromic sequence at each end, flanking the genes for transposition.

There is one tidbit of scientific history I wish to mention. In our first paper referred to above, I introduced the terms kilobase and $\mathrm{kb}$ for length measurements. I believe I used these terms in a talk I gave at a Cold Spring Harbor Symposium. In any case, the terms kilobase and kb caught on like wildfire and were and are universally used.

Madeline $\mathrm{Wu}$ came to my lab as a postdoctoral student at about the same time as Sharp. tRNA was too small to see by electron microscopy, but she and I developed a technique for ferritin labeling of the two tyrosine tRNAs on the transducing phage. The ferritin made the tRNA visible in the electron microscope. This was an exciting feat at the time (Figure 1) (8).

\section{STUDIES OF RNA}

In about 1972 I began studying RNA, especially the retroviruses (not all of which are oncogenic). Even in denaturing urea-formamide solvents, these viral RNAs were highly condensed and appeared "bushy" in the electron microscope. I 


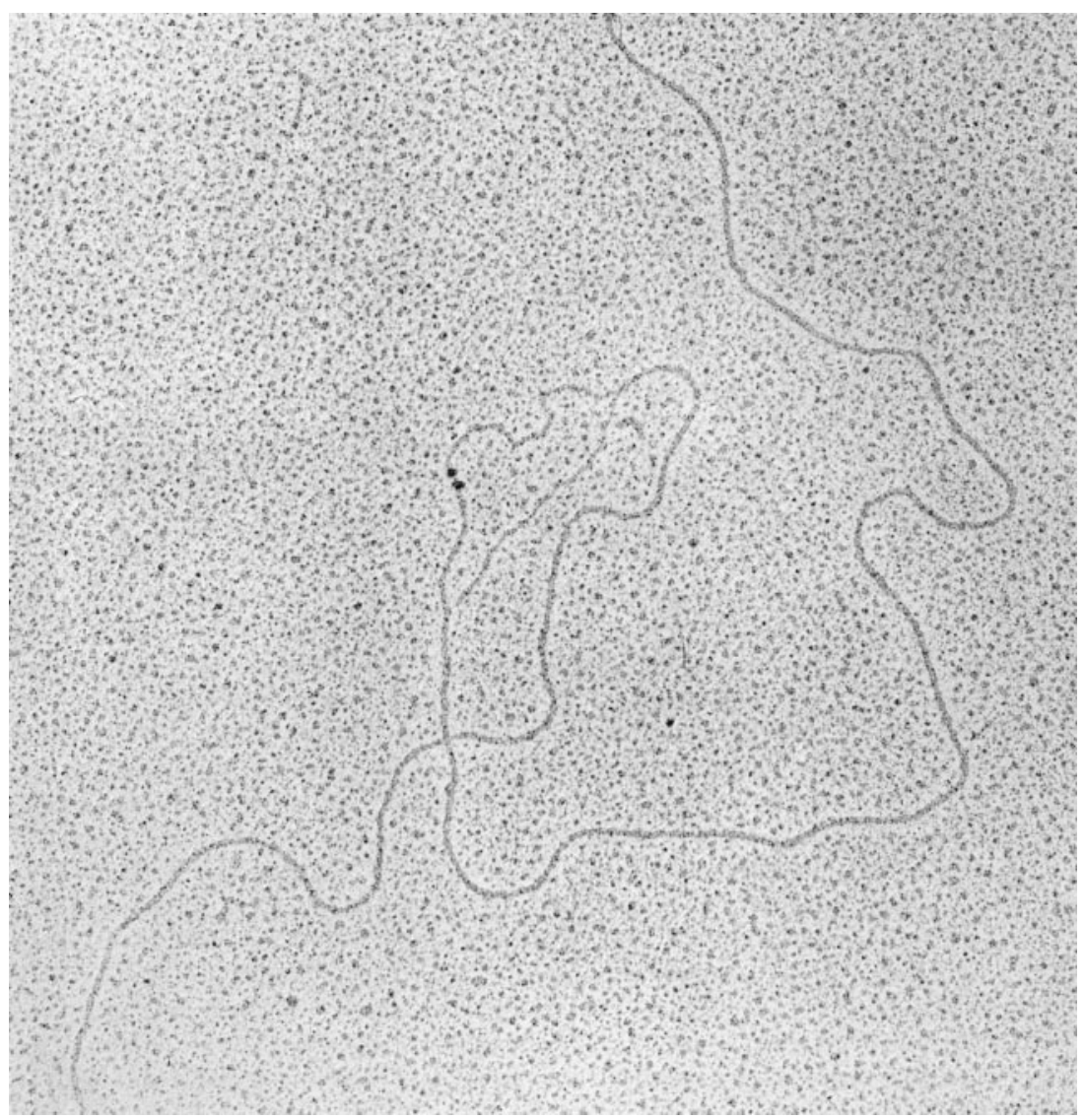

Figure 1 Electron micrograph of a heteroduplex with two ferritin labels on the transducing strand of a $\phi 80 \mathrm{hpsuIII} / \phi 80 \mathrm{~h}$ heteroduplex. Bacteriophage $\phi 80 \mathrm{~h}$ is closely related to bacteriophage $\lambda$.

reasoned that glyoxal (CHO-CHO) should react with the adjacent $-\mathrm{NH}$ and $-\mathrm{NH}_{2}$ groups of guanine. $\mathrm{GC}$ base pairs are the most stable base pairs in the Watson-Crick structure, and poly-rG was known to have a relatively stable secondary structure. Glyoxal treatment worked well, and in $40 \%-50 \%$ formamide spreads we saw well-extended RNA molecules. We did some of our initial work with a nononcogenic cat virus, RD-114, which had been isolated and studied in the laboratory of Dr. Robert McAllister at the Los Angeles Children's Hospital (11). It was known from sedimentation studies that the retroviruses as extracted from the virion were aggregates, probably dimers. The structures we saw in the electron microscope were clearly dimers that cohered at one end with a characteristic structure, which we called the dimer linkage structure. 
It was known that retrovirus RNA, like most mRNAs that are translated, contained poly(A) sequences. A question then was at which end of the RNA was the $\operatorname{poly}(\mathrm{A})$ sequence?

Welcome Bender, a graduate student with me, undertook this problem. We took SV40 DNA, a tumor virus duplex DNA that was locally available and was about $5 \mathrm{~kb}$ in length, nicked it lightly with DNaseI, and added dT tails of length about 400-500 nt with the enzyme, terminal transferase. When this was hybridized to the retrovirus RNA, we saw that the SV40 circles were attached to the end of the RNA opposite the dimer linkage structure (12) (Figure 2).

We continued for a while with our electron microscopic methods of investigating nucleic acids. Madeline $\mathrm{Wu}$ and I developed an electron microscopic method of observing the positions of proteins on a DNA molecule. We used a chemical method to attach the hapten dinitrophenyl to the protein that was attached to the DNA (for example, the protein that was bound to the two ends of adenovirus-2 DNA). By then adding an antibody to dinitrophenyl and, if necessary, a second antibody, we could observe the protein at each end.

Eric Fyrberg came to my laboratory as a postdoctoral fellow with an interest in Drosophila actin genes. With coworkers, we succeeded in cloning an actin gene, using a cloned Dictyostelim actin as a probe. By restriction mapping, we showed that there were six actin genes (13). Fyrberg and collaborators cloned all of them. In a later paper, we noted by DNA sequencing that all of the N-terminal sequences of the six genes were similar to those of vertebrate cytoskeletal actins (14). To my knowledge, it is not known which of the six code for skeletal muscle actins. (It is interesting to note that at that time DNA sequencing was done by the Maxam-Gilbert method.)

We carried out various other studies on Drosophila genes. Ronald L. Davis, now at Baylor Medical College (not to be confused with Ronald W. Davis at Stanford) came to my laboratory from the University of Utah to clone the dunce gene, which he had studied at Utah. It was known that this gene coded for one isoform of cAMP phosphodiesterase. Davis succeeded in his first clone isolation and gene characterization (15). In later studies from the Davis laboratory (16), it was shown that the gene was at least $145 \mathrm{~kb}$ in length, and some coding exons were omitted by some of the alternatively spliced forms. Studies from other laboratories showed that there were several proteins encoded by several of the many introns.

\section{NEUROBIOLOGY STUDIES}

At this point, I felt that it was a good time to go back to my earlier interest in neurobiology. Drosophila was not a good organism for this work because its neurons are too small for patch clamping, which was a highly developed skill for vertebrate cells. My colleague in the Biology Division at Caltech, Dr. Henry Lester, was interested in learning molecular biology, so we teamed up and 


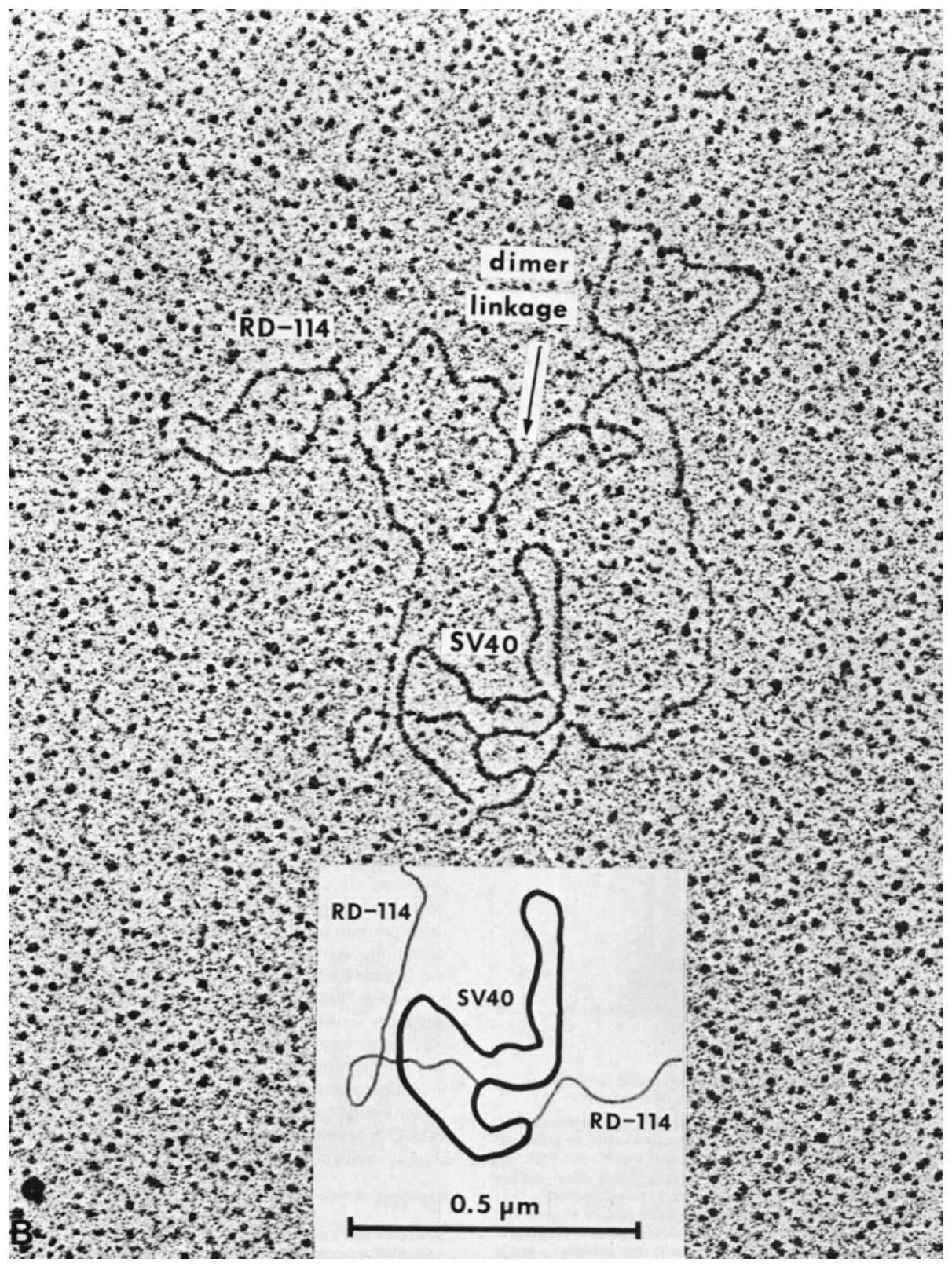

Figure 2 Electron micrograph showing a thymidine-tailed SV40 molecule hybridized to two short $\operatorname{poly}(\mathrm{A})$ stretches on the RNA of the RD-114 virus at the $3^{\prime}$ end, with the characteristic dimer linkage structure at the $5^{\prime}$ end. 
collaborated up to the present. In much of this early work, we used in vitro transcription of a linearized cDNA and injection of this mRNA, or a natural rat or mouse brain RNA, into Xenopus oocytes and used electrophysiological assays to characterize the gene or genes present. We initially studied the acetylcholine receptor gene (AcChoR).

Several other investigators, including the extremely effective laboratory of Shosaku Numa, had isolated and sequenced cDNA clones for the AcChoR. We received gifts of cDNA clones from several American investigators and screened a cDNA library in a suitable cloning vector. We isolated and sequenced one clone (17). By sequence criteria, this clone could be either a $\gamma$ or a $\delta$ clone. However, by injecting the RNA from this clone into Xenopus oocytes with combinations of the other subunits, we observed that functionally it is a $\delta$ subunit (18).

At about this time the molecular biology community in general, including my laboratory, gave up using electron microscopy as a tool for gene analysis. It has been replaced by recombinant DNA methodology, including DNA sequencing.

John Guastella came to our laboratory in about 1987 as a postdoctoral student for the specific purpose of cloning a GABA transporter. Using limited protein sequence data for a dodecapeptide, we designed degenerate oligonucleotide probes and isolated a cDNA clone, designated GAT-1, which in Xenopus oocytes caused the uptake of $\left[{ }^{3} \mathrm{H}\right] \mathrm{GABA}(19)$. Shortly afterwards, using an expression cloning strategy, Susan Amara and coworkers cloned a noradrenaline transporter (20).

There were several regions of sequence homology between these two transporters of quite disparate chemical structure. Using standard PCR methods, with degenerate oligonucleotide primers, many investigators cloned additional transporters.

The problem of inducible expression of a gene in eukaryotic cells was of interest to many molecular biologists. In about 1985, Mickey Hu, a postdoctoral student who was a skilled molecular biologist, and I conceived and executed the idea of using the lac operator-repressor system for this purpose. We first cloned the lac repressor gene, lacI, into a mammalian expression vector. We then constructed a reporter gene (CAT) with a 45-nt operator sequence inserted about 20-nt downstream of the TATA box, which is usually 20-40-nt upstream of the origin of transcription. The usual inducer of the lac operon in Escherichia coli is IPTG. This worked in mammalian cells too (21).

We were of course interested in the gene or genes coding for sodium channels. In a collaboration involving the Lester-Davidson laboratory and the laboratories of William Catterall in Seattle and Robert Dunn at the University of Toronto, we succeeded in cloning such a gene (22). Needless to say, the high-power laboratory of Shosaku Numa (23) had cloned a sodium channel gene several years before we did. Our sodium channel gene differed from that of Noda et al. (23) at six amino acid positions. It showed slower inactivation than this other channel when expressed by injecting rat brain RNA. We showed by coinjection of low molecular weight RNA that a lower molecular weight component, probably a $\beta$ 
subunit, also showed a shift of $20-25 \mathrm{mV}$ in the depolarization direction compared with rat brain RNA and to the Noda et al. clone. We later showed by PCR methods that both the Noda et al. clone and ours occurred in rat brain, with the former being about 15:1 more abundant (24).

In about 1985, Terry P. Snutch came to our laboratory to learn electrophysiology after receiving his Ph.D. at the University of British Columbia, Vancouver, in the Caenorhabditis elegans field. He participated in a number of good experiments and learned electrophysiology. He took part in many calcium channel studies. The main reason for mentioning this is that when he returned to British Columbia, Snutch, with his wife Mary Gilbert, sequenced a number of calcium channel genes and found that there are at least six isoforms; they basically opened up the calcium channel gene family for all investigators.

This is an appropriate time to mention that in 1989, as an emeritus professor, I transferred from the Chemistry Division to the Biology Division. Being in the Chemistry Division earlier was an advantage, because many graduate and postdoctoral students had been trained in chemistry but were interested in biology, so they chose to work with me. These include Ronald W. Davis, Phillip Sharp, and James Wang. This situation is less applicable now, because interested undergraduates usually take a degree in biology.

Henry Lester initiated my education about G-protein-coupled receptors (GPCRs). It was known that there was an inward rectifier potassium channel in the heart and that it was stimulated by muscarinic acetylcholine agonists.

With the help of two gifted experimenters, Nathan Dascal, then an assistant professor at Tel Aviv University, and Wolfgang Schreibmayer from the University of Graz in Austria, we used an expression cloning strategy with oocyte injection. After a number of rounds of rescreening we finally isolated the gene. This protein had the same hydrophobicity plot as ROMK1, an inward rectifier that was not G-protein gated. That is, it had an $\mathrm{N}$-terminal and a C-terminal cytosolic region, two membrane-spanning regions, and between them the characteristic P-loop that goes in and out of the membrane as seen in all inwardrectifying potassium channels (25).

Using homology probes deduced from the structure of another inward rectifier clone, the group of Lily Yeh Jan and Nun Yuk Jan cloned the same gene (26). In later work, we, the Jans' group, and another laboratory showed that it was $\mathrm{G} \beta \gamma$, not $\mathrm{G} \alpha$, that activated the GIRK1 channel (27-29). In the systematic notation for $\mathrm{K}$ channels adopted later, this channel is identified as Kir3.1. Three other G-protein-activated K channels are designated Kir3.2, Kir3.3, and Kir3.4.

We showed later that a $\mathrm{C}$-terminal peptide 17 amino acids long could block the GIRK channels (30). Presumably, this indicates that this cytosolic tail folds up to block the pore.

In 1993 Erin Schuman came to the Biology Division at Caltech. In her postdoctoral career at Stanford she and her mentor, Daniel Madison, had shown that $\mathrm{NO}$ as a second messenger, presumably released by a nitric oxide synthase in the postsynaptic cell and diffusing to the presynaptic cell, could cause 
long-term potentiation (LTP) (31). I was fascinated by this. At the time I was developing the use of adenovirus for gene transfer into neurons. Neuronal nitric oxide synthase (nNOS) knock-out mice still expressed LTP. This suggested that endothelial NOS (eNOS), which despite its name was known to occur in the dendrites of hippocampal neurons, was the contributing enzyme for LTP. Furthermore, it had been shown that an inhibitor of myristoylation would inhibit LTP. We therefore engineered a gene containing the signal sequence of CD8 (which occurs on the cell membrane of T cells) fused to the eNOS gene. We observed that with this gene, eNOS expression on the cell surface of neurons in rat hippocampal slices was not blocked by a myristoylation inhibitor and that tetanically induced LTP was expressed (32).

At Caltech, Dr. Schuman, with gifted graduate student H. Kang, followed up the work of earlier investigators (33) and showed that brain-derived neurotrophic factor (BDNF) could induce long-lasting enhancement of synaptic transmission (34). We were excited by this work. We followed up by studying the effects of BDNF on E18 neurons in culture. We first showed that BDNF could enhance synaptic transmission between a synaptically connected cell pair (35).

The trkB membrane-associated protein is the receptor for BDNF. TrkB functions as a dimer. Presumably, when the two monomer components are pulled together by binding BDNF, the tyrosine kinase activity of this protein is activated. We made a dominant negative trkB by deleting the intracellular portion of the gene and fusing a green fluorescent protein to the $\mathrm{C}$ terminus. This was expressed on E18 rat hippocampal neurons in culture. From fluorescence observations, we could tell whether a presynaptic cell or a postsynaptic cell was expressing the dominant negative trkB. We then observed that only when the presynaptic cell was infected could we observe an inhibition of the BDNF enhancement of transmission (36). Thus, at least for short-term activation, the effect of BDNF is presynaptic.

We then took up further studies on LTP. We used organotypic cultures from E18 rats. Unlike the acute slices from adult rats that are used by other investigators, these cultures can be maintained for at least 3-4 weeks and therefore are more suitable for viral-mediated gene transfer. We have not yet had the opportunity to test the effects of injection of a virus into these slices, but we have made one interesting observation.

The membrane-permeant and relatively stable analog of cAMP that is used by many authors (see e.g., Reference 37) is Sp-cAMPS. There is another isomer of this molecule, Rp-cAMPS, which is an inhibitor of PKA, the enzyme activated by cAMP.

A postdoctoral fellow, Tzu-ping $\mathrm{Yu}$, was studying the effects of Sp-cAMPS on synaptic transmission in CA1 neurons of an organotypic culture. She did indeed see an enhancement of transmission by Sp-cAMPS, which was blocked by the PKA inhibitor, Rp-cAMPS. Because of anomalous effects in one experiment, she tested the effect of the GABA-A inhibitor, picrotoxin. To our great surprise, she observed LTD with a mixture of Sp-cAMPS and picrotoxin. This 
effect is unexplained and counterintuitive. It develops slowly and is blocked by the protein synthesis inhibitor anisomycin (38). We are continuing to study this phenomenon.

\section{LITERATURE CITED}

1. Carrington T, Davidson N. 1953. J. Phys. Chem. 57:418-43

2. Dove WF, Davidson N. 1962. J. Mol. Biol. 5:467-78

3. Yamane T, Davidson N. 1961. J. Am. Chem. Soc. 83:2599-607

4. Davidson N, et al. 1965. Proc. Natl. Acad. Sci. USA 53:111-14

5. Wang JC, Davidson N. 1996. J. Mol. Biol. $15: 111-23$

6. Wetmur JG, Davidson N. 1968. J. Mol. Biol. 31:349-70

7. Sharp PA, et al. 1972. J. Mol. Biol. 71:491-97

8. Wu M, Davidson N. 1973. J. Mol. Biol. 78:23-34

9. Davis RW, Davidson N. 1968. Proc. Natl. Acad. Sci. USA 60:243-50

10. Westmoreland B, et al. 1968. Science 60:243-48

11. Kung H-J, et al. 1974. J. Virol. 14:170-73

12. Bender W, Davidson N. 1976. Cell 7:609-20

13. Fyrberg EA, Kindle KL, Davidson M. 1980. Cell 19:365-78

14. Fyrberg EA, Bond BJ, Hershey ND, Mixter KS, Davidson N. 1981. Cell 24:107-11

15. Davis RL, Davidson N. 1983. Mol. Cell. Biol. 4:358-67

16. Qiu YH, et al. 1991. J. Mol. Biol. 222: 553-65

17. LaPolla RJ, et al. 1981. Proc. Natl. Acad. Sci. USA 81:7970-74

18. White MM, et al. 1985. Proc. Natl. Acad. Sci. USA 82:449-53
19. Guastella JG, et al. 1990. Science 249: 1303-6

20. Pachalcyzk T, et al. 1991. Nature 350: 350-59

21. $\mathrm{Hu}$ M-CT, Davidson N. 1987. Cell 48:556-66

22. Auld VJ, Goldin AL, Krafte KS, Marshall J, Dunn JM, et al. 1988. Neuron $1: 449-61$

23. Noda M, et al. 1986. Nature 322:826-88

24. Ahmed CMI, Auld VJ, Lester HA, Dunn R, Davidson N. 1990. Nucleic Acids Res. 18:5907

25. Dascal N, Schreibmayer W, Lim NF, Wang W, Chavkin C. 1993. Proc. Natl. Acad. Sci. USA 90:10235-39

26. Kubo Y, Reuveny E, Slesinger PA, Jan YN, Yan LY. 1993. Nature 364:758-59

27. Lim NF, et al. 1995. J. Gen. Physiol. 105:421-39

28. Reuveny E, Slesinger PA, Inglese J, Morales JM, Iniguez-Lluhi JA, et al. 1994. Nature 370:143-46

29. Takao K, Yoshi M, Kanda A, Kokubun S, Nukada T. 1994. Neuron 13:747-55

30. Dascal N, Doupnik CA, Ivanina T, Bausch S, Wang W. 1995. Proc. Natl. Acad. Sci. USA 92:6758-62

31. Schuman EM, Madison DV. 1994. Science 263:532-35

32. Kantor DB, et al. 1996. Science 274:1744-48

33. Lobo AM, Poo MM. 1993. Nature 363: 350-53 
34. Kang H, Schuman EM. 1995. Science 267:1658-62

35. Li Y-X, Zhang Y, Lester HA, Schuman EM, Davidson N. 1998. J. Neurosci. 18:10231-40

36. Li YX, Xu YF, Ju DS, Lester HA, David- son M, Schuman EM. 1998. Proc. Natl. Acad. Sci. USA 95:10884-89

37. Frey U, et al. 1993. Science 260:1661-64

38. Yu T-P, McKinney S, Lester HA, Davidson M. 2001. Proc. Natl. Acad. Sci. USA 98:5264-69 


\section{CONTENTS}

FrontISPIECE-Norman Davidson xii

My Career in Molecular Biology, Norman Davidson xiii

FrontisPIECE-Thressa Campbell Stadtman xxvi

Discoveries of Vitamin $B_{12}$ And Selenium Enzymes,

Thressa Campbell Stadtman

Error-Prone Repair DNA Polymerases in Prokaryotes and EUKARYOTES, Myron F. Goodman 17

Long-Distance Electron Transfer Through DNA, Bernd Giese 51

The Bacterial RecA Protein and the Recombinational DNA Repair of Stalled Replication Forks, Shelley L. Lusetti and Michael M. Cox 71

V(D)J Recombination: RAG Proteins, Repair Factors, AND REgUlation, Martin Gellert

EukARYotic DNA Polymerases, Ulrich Hübscher, Giovanni Maga, and Silvio Spadari

Eukaryotic Ribonuclease P: A Plurality of Ribonucleoprotein EnZymes, Shaohua Xiao, Felicia Scott, Carol A. Fierke, and David R. Engelke

Active Site Tightness and Substrate Fit in DNA Replication, Eric T. Kool

Great Metalloclusters in Enzymology, Douglas C. Rees

ATP-Dependent Nucleosome Remodeling, Peter B. Becker and Wolfram Hörz

Biological Roles of Proteases in Parasitic ProtozoA, Michael Klemba and Daniel E. Goldberg

Metabolism and the Control of Circadian Rhythms, Jared Rutter, Martin Reick, and Steven L. McKnight

DNA Replication in Eukaryotic Cells, Stephen P. Bell and Anindya Dutta

The La Protein, Sandra L. Wolin and Tommy Cedervall

Lipoprotein ReCEPTORS IN THE NeRvous System, Joachim Herz and Hans H. Bock 
Order Out of Chaos: Assembly of Ligand Binding Sites in Heparan Sulfate, Jeffrey D. Esko and Scott B. Selleck

Neuronal $\mathrm{CA}^{2+} /$ Calmodulin-Dependent Protein Kinase II: The Role of Structure and Autoregulation in Cellular Function, Andy Hudmon and Howard Schulman

Biochemistry of NA,K-ATPAse, Jack H. Kaplan

Mammalian ABC Transporters in Health and Disease, $P$. Borst and R. Oude Elferink

Homogeneous Glycopeptides and GLyCOPROTEINS FOR BiologicAL Investigation, Michael J. Grogan, Matthew R. Pratt, Lisa A. Marcaurelle, and Carolyn R. Bertozzi

LiPOPOLYSACCHARIDE ENDOTOXINS, Christian R. H. Raetz and Chris Whitfield

Formation of Unusual Sugars: Mechanistic Studies and Biosynthetic Applications, Xuemei M. He and Hung-wen Liu

Nuclear Actin and Actin-Related Proteins in Chromatin Remodeling, Ivan A. Olave, Samara L. Reck-Peterson, and Gerald R. Crabtree

Mechanisms of Fast Protein Folding, Jeffrey K. Myers and Terrence G. Oas

RNA Editing by Adenosine Deaminases That Act on RNA, Brenda L. Bass

Catalytic Proficiency: The Unusual Case of OMP Decarboxylase, Brian G. Miller and Richard Wolfenden

Catalytic Strategies of the Hepatitis Delta Virus Ribozymes, I-hung Shih and Michael D. Been

INDEXES

$\begin{array}{ll}\text { Author Index } & 919\end{array}$

Subject Index $\quad 995$

Cumulative Index of Contributing Authors, Volumes 67-71 1035

Cumulative Index of Chapter Titles, Volumes 67-71

\section{ERRATA}

An online log of corrections to Annual Review of Biochemistry chapters may be found at http://biochem.annualreviews.org/errata.shtml 